\title{
Kemampuan Pemain Teater Cepung Lombok sebagai Kekayaan Dramaturgi Tradisional
}

\author{
Salman Alfarisi \\ Fakulti Muzik dan Seni Persembahan, Universiti Pendidikan Sultan Idris, Malaysia
}

\begin{abstract}
Abstrak
Artikel ini mendiskusikan tentang fenomena Teater Cepung Lombok di tengah masyarakat Sasak. Dengan menggunakan metode kualitatif, artikel ini berpijak pada keinginan untuk mengetahui tentang Teater Cepung Lombok, khususnya mengenai pemain yang secara tradisional memiliki kemampuan untuk menafsirkan teks Tutur Monyeh sebagai sumber penciptaan Teater Cepung. Meneropong dengan teori teks, artikel ini menunjukkan bahwa Teater Cepung merupakan produk kesenian asli Lombok yang menonjolkan kekuatan pemain sebagai keutamaan dalam pementasan. Meskipun dikategorikan tradisional, namun pemain teater Cepung pada hakikatnya memberikan ruang baru untuk memahami kekayaan bentuk dramaturgi Indonesia.
\end{abstract}

Kata kunci: Teater Cepung, Teater Tradisional, Kemampuan Pemain

\begin{abstract}
This article discusses about the phenomenon of Cepung Lombok Theatre in Sasak community. Using the qualitative methode, this article emphasizes on the need to know about Cepung Lombok Theatre, specifically the actors who traditionally have the ability to interpret the Tutur Monyeh text as the source of Cepung Theatre. Using the text theory, this article shows that Cepung Theatre is an original art production of Lombok which accentuates the strength of the actor in the stage. However, even though Cepung Theatre is categorized as a traditional theatre, the actors essentially give new ways to comprehend the dramaturgy of Indonesia.
\end{abstract}

Keywords : Cepung Theatre, traditional theatre, actor's ability 


\section{Pendahuluan}

Kesenian tidak dapat dipisahkan dari manusia sebagai pelaku dan kebudayaan yang digunakan sebagai kerangka acuannya dalam berperilaku di masyarakat (Subiyantoro: 1999:343). David Levinson dan Melvin E. mengatakan kesenian adalah bagian dari kebudayaan (Asy'ari, 2001: 282). Dalam hubungannya dengan teater Cepung, relevansi pendapat ini dapat ditemukan pada sumber penciptaan teater Cepung, penulis naskah teater Cepung, pemain, dan keterkaitan antara teater Cepung dengan masyarakat Sasak sebagai pendukung kesenian tradisional ini.

Sumber penciptaan teater Cepung adalah lontar Tutur Monyeh yang merupakan karya sastra lokal (Sasak) yang berisi tentang nilai keislaman dengan menggunakan bahasa Sasak campuran antara bahasa Sasak rendah dan menengah. Penggunaan bahasa Sasak sebagai bahasa lontar Tutur Monyeh merupakan salah satu tanda bahwa teater Cepung merupakan produk budaya masyarakat Sasak. Fungsi bahasa Sasak dalam lontar Tutur Monyeh adalah sebagai penegasan identitas masyarakat Sasak dalam membangun peradaban mereka.

Lontar yang dibacakan dalam pertunjukan Cepung adalah Lontar Monyeh yang dikarang oleh seorang bernama Jero Mihram, seorang ulama Islam yang ingin mengembangkan agama Islam melalui ceritera dan digemari oleh penduduk pulau Lombok. Dari hal tersebut jelaslah bahwa Lontar Monyeh dalam pertunjukan teater Cepung ini sebenarnya berlatar belakang falsafah Islam dan dikarang dengan tujuan mengembangkan suatu agama (Ahmad,1987: 165).

Teater Cepung merupakan teater tradisional Lombok yang memiliki tempat tersendiri di tengah masyarakat Sasak, baik struktur maupun tekstur pertunjukannya. Kehadiran teater Cepung memberikan kontribusi membentuk karakter masyarakat Sasak dengan fungsinya sebagai salah satu media pendidikan moral masyarakat Sasak, juga keterlibatannya dalam beberapa upacara, bahkan sebagai salah satu media penyampai pesan kritik. Struktur pertunjukan teater Cepung menonjolkan tiga unsur seni teater secara bersamaan, yakni unsur nyanyian, tarian, dan lakuan. Aspek seni dalam teater Cepung adalah seni drama dan seni sastra, seni musik dan seni suara, seni tari (Ahmad, t.t: 167-169).

Salah satu komponen penting dalam pertunjukan teater Cepung ialah pemain. Merekalah yang menjadi penafsir awal lontar Tutur Monyeh sehingga beragam kemungkinan dapat terjadi dalam setiap pementasan di luar pertunjukan baku teater Cepung. Lontar Monyeh yang tadinya berupa 
teks dapat menjadi konteks karena pemain dapat menyerap dengan cepat peristiwa di sekitar pementasan. Dalam situasi semacam inilah kelisanan mereka menjadi tumpuan. Respons terhadap keadaan sosial masyarakat sekitar termasuk memberikan sapaan kepada penonton ialah bagian yang tidak terpisahkan dari kemampuan mereka. Tidak jarang mereka seperti keluar dari teks Lontar Monyeh, tetapi sebenarnya mereka sedang mempraktikkan kemampuan melisankan teks sehingga teks dapat menemukan makna dan fungsinya secara nyata di tengah masyarakat.

Merujuk pada pandangan di atas, artikel ini hendak mendeskripsikan tentang pemain teater Cepung Lombok dengan mengacu kepada pertanyaan seperti berikut. Bagaimanakah awal mula munculnya teater Cepung Lombok? Bagaimanakah pemain teater Cepung Lombok menggunakan tubuh sebagai alat tafsir terhadap teks Lontar Monyeh? Kemampuan apa saja yang dimiliki oleh pemain teater Cepung Lombok dalam membaca konteks masyarakat?

\section{Landasan Teori}

Teori teks dianggap sebagai hipologi. Hypos adalah rajutan, tenunan, jaringan sehingga teori teks adalah teori tentang jaringan (Yudiaryani, 2008: 132). Seperti yang sudah dijelaskan sebelumnya bahwa teater Cepung merupakan pertunjukan yang terbentuk dari berbagai aspek. Untuk itu, kajian terhadap teater Cepung harus pula disertakan kajian kontekstual dan ko-tekstual, sehingga dapat ditemukan keterhubungan antara teater Cepung dengan teori teks. Oleh karena teks pertunjukan merupakan rajutan atau tenunan dari berbagai aspek pertunjukan, baik aspek yang di luar pertunjukan itu sendiri, yakni aspek kontekstual atau aspek eksternal dari pertunjukan yang berupa aspek budaya dan aspek ketika pertunjukan sedang berlangsung, maupun aspek ko-tekstual yang terdiri dari aspek internal pertunjukan berupa penataan panggung, cahaya, bunyi, keaktoran (Yudiaryani, 2008: 128-130), maka kajian teks pertunjukan terhadap teater Cepung juga meliputi aspek internal.

"Teater dalam konteksnya
sebagai kesenian yang
berbicara tentang sosial-
budaya manusia merupakan
sesuatu yang harus "dibaca"
dan "ditafsirkan", dan
seperti halnya sebuah teks
yang pembacanya boleh
memberikan tafsir apa saja
dengan bebas, demikian pula
terhadap kesenian. Dia juga
boleh ditafsirkan dengan bebas
oleh para penontonnya" (Putra,
1988: 20).

Menurut Barba, sebuah pertunjukan teater dapat didekati atau dianalisis berdasarkan spektakel dari teks tertulis, dan pendekatan dari teks panggung (Yudiaryani, 2002: 295). Sebagaimana sudah dikemukakan bahwa pertunjukan teater Cepung tidak bisa 
dilepaskan dari teks tertulisnya, yakni Tutur Monyeh, maka apa yang diperlihatkan oleh pertunjukan teater Cepung merupakan kemampuan pemainnya dalam menyerap setiap yang tertampilkan dalam Tutur Monyeh.

Dalam teater Cepung, berbagai rajutan tersebut dapat dipahami sebagai salah satu kemampuan pemain dalam merajut setiap nilai yang terkandung dalam Tutur Monyeh untuk dijadikan sebagai sebuah pertunjukan yang dipahami dan diterima sebagai nilai hidup bagi masyarakat Sasak. Ketika berbicara tentang bentuk pertunjukan teater Cepung sudah berarti terkandung makna di dalamnya karena secara keseluruhan pertunjukan teater Cepung seperti yang dimaksudkan integralitas antara bentuk dan makna. Misalnya, cara pemain membawakan atau menceritakan salah satu peristiwa dalam teater Cepung sudah mencakup makna yang hendak disampaikan di dalamnya.

\section{Metode Penelitian}

Berpijak pada persoalan dalam artikel, untuk mendapatkan data sebanyakbanyaknya tentang teater Cepung diperlukan metode penelitian kualitatif. Dalam penelitian kualitiatif sebuah data kita anggap sebagai sebuah totalitas (Soedarsono, 2001: 34). Secara umum, pemerolehan data dalam artikel menggunakan metode kualitatif karena data dari bermacam sumber, biasanya dari wawancara dan pengamatan (Strauss dan Corbin, 2007: 7). Selanjutnya, data tentang teater Cepung dideskripsikan setelah melalui proses pengolahan dan interpretasi data. Whitney mengatakan bahwa metode deksriptif adalah pencarian fakta dengan interpertasi tepat (dalam Nazir, 2005: 54).

Melihat metode penelitian dan segala sifat-sifatnya di atas, terlebih dengan fenomena teater Cepung Lombok yang sejauh ini belum banyak diangkat ke permukaan, maka teknik pengumpulan data melalui kepustakaan.

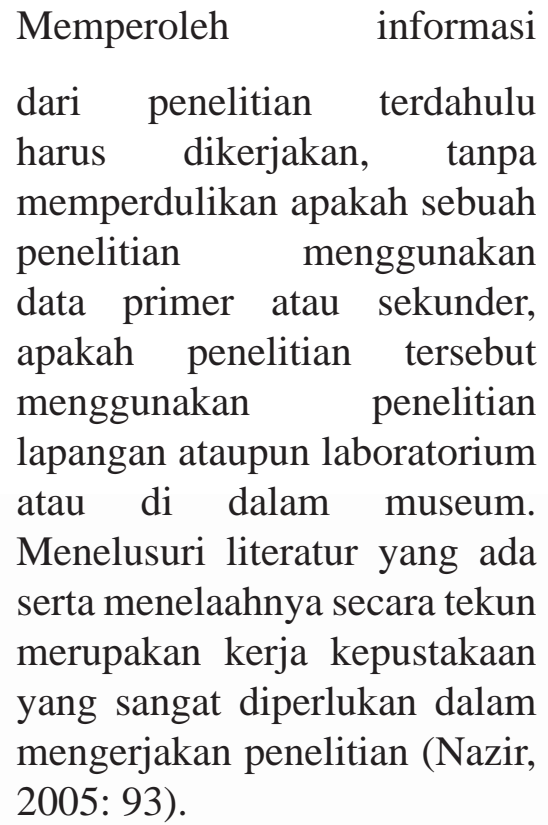

Kepustakaan pada prinsipnya bersifat pembacaan dan pengkajian pustakapustaka, baik yang sudah berupa buku, artikel atau tulisan-tulisan lain mengenai teater Cepung sehingga dapat membantu penambahan atau pengayaan data. Selain itu, kepustakan ini akan membantu menemukan keterkaitan antara teori yang digunakan. 
Teknik pengumpulan data berikutnya adalah observasi. Usaha pengamatan atau observasi yang cermat dapat dianggap salah satu cara penelitian ilmiah yang paling sesuai bagi peneliti (Bachtiar, 1977: 137). Pengumpulan data dengan observasi langsung atau dengan pengamatan langsung adalah cara pengambilan data dengan menggunakan mata tanpa ada pertolongan alat standar lain untuk keperluan tersebut (Nazir, 2005: 175). Pada prinsipnya kegiatan observasi membantu proses wawancara, tetapi observasi yang dimaksudkan dalam artikel ini ialah berfungsi untuk menemukan data yang dipandang berkembang, yakni untuk menjaga kemungkinan ditemukannya fenomena lain di lapangan yang menyangkut teater Cepung. Salah satu bentuk observasi ini adalah menonton secara langsung pertunjukan teater Cepung.

Teknik pengumpulan data berikutnya adalah wawancara, yakni percakapan dengan maksud tertentu. Percakapan itu dilakukan oleh dua pihak, yaitu pewawancara atau (interviewer) yang mengajukan pertanyaan dan terwawancara yang memberikan jawaban atas pertanyaan itu. Wawancara merupakan proses interaksi antara pewawancara dengan responden. Walaupun bagi pewawancara, proses tersebut adalah satu bagian dari langkah-langkah dalam penelitian, tetapi belum tentu bagi responden, wawancara adalah bagian dari penelitian
(Nazir, 2005: 186-194).

Proses mendapatkan data melalui wawancara dijelaskan bahwa wawancara dibagi menjadi dua jenis, pertama, wawancara untuk mendapatkan keterangan dan data dari individu-individu tertentu untuk keperluan informasi. Kedua, wawancara untuk mendapatkan keterangan tentang diri pribadi, pendirian atau pandangan dari individu yang diwawancara untuk keperluan komparatif (Koentjaraningrat, 1989:130).

Sebelum melakukan wawancara, terlebih dahulu dipersiapkan daftar pertanyaan yang akan diajukan kepada narasumber sehingga tujuan, sasaran, dan target wawancara tercapai dengan maksimal. Akan tetapi, untuk menghindari kekakuan atau kebuntuan saat wawancara, dilakukan wawancara bersifat terbuka. Narasumber yang berasal dari seniman teater Cepung sendiri berjumlah dua orang karena hanya dua orang yang masih tersisa dari seniman teater Cepung senior yang lain. Namun demikian, untuk mematangkan hasil wawancara dari kedua seniman teater Cepung yang masih ada, seterusnya dilakukan wawancara dengan narasumber sejarawan-budayawan, pakar tradisi lisan Lombok, dan seorang birokrat kesenian.

Selanjutnya, teknik analisis data yang digunakan dalam penelitian ini adalah deskriptif kualitatif, yakni suatu analisis 
yang berusaha menggambarkan data sejelas mungkin dengan disertai penjelasan interpretasi secara teoretis (Wignjosoebroto, 1989:269). Langkah analisis data mencakup beberapa tahapan. Pertama, data yang terkait dengan teks dramatik teater Cepung yang berupa TuturMonyeh. Kedua, mengklasifikasi bagian-bagian struktur pertunjukan teater Cepung. Ketiga, menafsirkan makna yang terdapat di dalam struktur pertunjukan teater Cepung. Keempat, mendeskripsikan fungsi teater Cepung bagi masyarakat Sasak. Kelima, menggali lebih jauh peran teater Cepung sehingga mengetahui bagaimana peran teater Cepung membangun kontekstualitas dengan masyarakat Sasak.

\section{Pembahasan}

\section{a. Sekilas tentang Masyarakat Sasak}

Penduduk asli yang mendiami pulau Lombok disebut Sasak. Masyarakat Sasak merupakan suatu ras tipe Melayu yang diperkirakan sudah tinggal di Lombok selama lebih dari 3000-an tahun yang lalu dan diperkirakan sudah menduduki daerah pesisir pantai sudah 4000 -an tahun yang lalu (Suwadi, 1991: 7). R. Goris menguraikan arti kata Sasak secara etimologis, yakni Sasak adalah kata Sanskerta yang berasal dari kata sahsaka. Sah berarti pergi dan saka berarti Asal. Jadi, orang Sasak adalah orang yang pergi dari negeri asal dengan memakai rakit sebagai kendaraan. Pergi dari Jawa dan berkumpul di Lombok (dalam Wacana, 1988: 9-10).

Teeuw mengatakan bahwa Sasak berasal dari keadaan penduduk asli pulau Lombok yang memakai kain tembasaq yakni kain putih. Perulangan dari kata tembasaq menjadi saqsaq yang memberikan arti Sasak (dalam Wacana, 1988: 10). Apabila merujuk dari perjalanan kebudayaan masyarakat Sasak yang tidak terlalu banyak mengenal warna putih, maka pendapat Teeuw ini memiliki kelemahan karena warna dalam penggunaan pakaian masyarakat Sasak, terutama kain-kain songket dan kain tenunan lebih dominan atau lebih dikenal warna cokelat tanah dan warna hitam. Sama halnya dengan ornamen-ornamen kerajinan yang berkembang di tengah masyarakat Sasak. Selanjutnya, etnik Sasak merupakan penganut Islam yang taat. Peran penting tokoh agama sejak Islam masuk ke Lombok menjadi salah satu kunci pemahaman dan kesasadaran keislaman masyarakat Sasak yang terbilang tinggi. Fase keislaman mereka pun berevolusi sesuai dengan konteks sosial dan politik yang dihadapi. Salah satunya ialah fase patriotik yang dapat dijumpai dalam lontar Tutur Monyeh yang dipentaskan pada teater Cepung. Agama Islam masuk ke tengah masyarakat Sasak diperkirakan sekitar abad ke-16 yang disebarkan dari Jawa oleh Sunan Prapen, anak dari Sunan Giri, yang 
merupakan salah seorang dari Walisongo. Dengan demikian, dapat diketahui bahwa penyebar agama Islam ke pulau Lombok adalah Walisongo (Zakaria, 1998: 46). Pernyataan ini menunjukkan bahwa Islam Lombok memiliki garis sejarah dengan Islam Jawa dan Nusantara sehingga simbol kebudayaan dan keislaman masyarakat Sasak banyak menunjukkan kesamaan dengan Jawa dan Nusantara sebagaimana yang dijumpai dalam teater Cepung.

\section{b.Awal Mula Teater Cepung}

Pada dasarnya masyarakat Sasak tidak mengenal istilah teater, musik, atau tari dalam seni tradisi mereka, misalnya teater Cupak Gerantang hanya disebut Cupak Gerantang saja meskipun jenis kesenian ini mengandung unsur pertunjukan teater tradisional yang dapat dilihat dari pola pementasan dan unsur-unsur teater lainnya yang terdapat dalam pertunjukan tersebut. Begitu juga dengan musik cilokaq atau musik penting. Kedua jenis kesenian ini tetap disebut sebagai cilokaq atau menting atau begambus meskipun kedua jenis kesenian ini dapat dikategorikan sebagai jenis musik tradisional masyarakat Sasak. Demikian juga dengan tari jangger atau tari joged. Kesenian ini dikenal atau disebut jangger atau joged meskipun termasuk ke dalam jenis seni tari.

Pemberian nama seperti ini pada satu sisi memberikan makna yang cukup luas. Artinya, masing-masing kesenian yang ada tidak disebut sesuai dengan jenisnya melainkan sesuai dengan nama kesenian tersebut sehingga unsur yang ada di dalamnya menjadi kesatuan dengan nama kesenian yang dimaksudkan. Penamaan semacam ini tentu akan memberikan kekayaan makna bagi kesenian tersebut, tetapi sekaligus dapat mempersempit istilah yang ada di dalamnya ketika dilakukan pengkategorisasian.

Hal serupa juga terjadi pada teater Cepung. Meskipun dalam jenis kesenian ini ditemukan unsur teater, masyarakat Sasak tetap menyebutnya sebagai Cepung saja. Bahkan, pemainnya sendiri ketika sedang berlangsung pertunjukan menyebutnya sedang becepung. Awalan "be" dalam kata Cepung menunjukkan satu jenis kata kerja sehingga becepung dapat diartikan sedang bermain teater Cepung. Awalan " $b e$ " di tengah masyarakat Sasak digunakan untuk menunjukkan suatu pekerjaan atau menunjukkan satu "kata kerja". Misalnya, orang sedang bernyanyi disebut "benyanyi" dan lain sebagainya. Hal inilah yang membuka kemungkinan seni "Cepung" yang dikenal luas di tengah masyarakat Sasak disebut sebagai "teater" Cepung, selain unsur-unsur yang ada di dalam struktur pertunjukan dan konteks pertunjukannya.

"Dengan menggunakan kata teater, kita mampu mengetahui seluruh warsian budaya sastra drama, atau bahkan hanya 
beberapa bentuk pementasan seperti mime, pantomime, pertunjukan rakyat kabaret, monolog, wayang kulit, dan wayang golek. Lebih luas lagi, saat ini kata teater juga digunakan untuk menyebut pertunjukan atau tempattempat yang terkait dengan wilayah film, radio, serta televisi. Teater merupakan kerja seni yang paling obyketif. Selain itu, teater merupakan kerja seni yang paling kompleks. Hal ini disebabkan teater menuntut kehadiran seniman, aktor, penulis naskah, sutradara, pemusik, pelukis, penata lampu, koreografer dan lain sebagainya untuk menggabungkan kreativitasnya", (Yudiaryani, 2002: 1-8).
Pandangan di atas menggambarkan

kompleksitas unsur seni yang ada dalam teater yang secara umum dapat disebut penggabungan antara seni rupa, seni pertunjukan, dan seni audio visual. Dengan demikian, melihat kompleksitas seni yang ada dalam "Cepung" dan makna yang diberikan oleh kata "teater" maka tepat apabila seni ini disebut dengan teater Cepung. Dalam artikel ini untuk selanjutnya "Cepung" akan disebut sebagai teater Cepung.

Teater Cepung ${ }^{1}$ merupakan seni pertunjukan teater tradisional khas atau asli Lombok yang elemen pembentukannya berangkat dari tradisi atau kebiasaan masyarakat Sasak pada masa terdahulu.

$1 \quad$ Karena pengkajian terhadap teater Cepung Lombok belum dilakukan secara mendalam, dan hasil penulisan tentang teater Cepung yang dilakukan oleh instansi pemerintah di Nusa Tenggara Barat yang terkait dengan kesenian dan kebudayaan tidak dipublikasi secara meluas, maka masyarakat umum banyak beranggapan bahwa teater Cepung Lombok adalah teater Cakepung yang dimaksudkan di Karangasem Bali. Padahal dalam kedua nama seni ini terdapat perbedaan sekaligus persamaan. Kalau mengacu kepada tulisan I Komang Sudirga dalam buku yang berjudul "Cakepung, Ansambel Vokal Bali" (2005) ditemukan persamaan pada kedua jenis seni ini, yakni pada sumber pertunjukannya yaitu lontar Tutur Monyeh. Dalam buku ini, Sudirga mengambil kesimpulan bahwa Cakepung yang ada di Karangasem Bali berasal dari Lombok karena teater Cepung sudah ada di Lombok sekitar pertengahan abad ke-18. Namun demikian, perbedaan mendasar antara teater Cepung dengan Cakepung adalah teater Cepung berkarakteristik Islam dan fungsinya tidak semata sebagai media ritual, melainkan juga memiliki hubungan kontekstual dengan sejarah masyarakat Sasak, baik sosial, agama, dan Politik. Ritual dalam teater Cepung masih kental nilai-nilai Islam. Berbeda dengan Cakepung yang dalam istilah Sudirga mengkategorikan Cakepung sebagai seni balih-balihan karena fungsinya yang paling dominan adalah untuk menghibur. Struktur pertunjukan teater Cepung dengan Cakepung pun berbeda. Misalnya, Cakepung menghadirkan peristiwa dalam lontar Tutur Monyeh ke dalam bentuk lakuan dengan menirukan gerakangerakan Monyeh atau kera, sedangkan teater Cepung tidak demikian karena substansi dari struktur pertunjukan teater Cepung berasal dari nilai-nilai Islam dan semangat patriotisme masyarakat Sasak. Dengan demikian dapat dikatakan bahwa kedua seni yang memiliki persamaan sekaligus perbedaan ini merupakan kesenian yang menjadi milik masyarakat masing-masing yang patut dihargai sebagai sebuah karya kesenian nenek moyang masyarakat Sasak yang melahirkan teater Cepung dan Cakepung yang tumbuh di masyarakat Karangasem Bali. 
Elemen yang dimaksudkan adalah pinje panje, pepaosan, bekayaq. ${ }^{2}$ Pinje panje pada pertunjukan teater Cepung dapat dilihat pada tembang-tembang yang menyindir secara tersembunyi dan halus terhadap berbagai fenomena masyarakat, baik kalangan atas maupun bawah. Sindiran halus ini, salah satunya dapat dilihat pada cara teater Cepung menyindir pedagang dari Banjarmasin dan Palembang dengan sebutan "Encek" Begitu juga ketika menyindir dengan cara yang sangat halus tentang perbedaan dengan etnik Bali dengan masyarakat Sasak. Meskipun pinje panje di tengah masyarakat Sasak jarang yang tertulis (lisan), tetapi dalam pertunjukan teater Cepung, pola tersebut terdapat dalam tembang yang tertulis, yakni dalam lontar Tutur Monyeh. Kemudian tradisi pembacaan lontar sambil dinyanyikan lewat tembangtembang ini disebut pepaosan.

"Dalam realitas sosialnya, pinje panje sering digunakan tidak saja untuk mengungkapkan perasaan seseorang yang harus dibalas (dijawab/dijawab) oleh lawan

2 Bekayaq adalah kebiasaan masyarakat Sasak menyanyikan pantun-pantun, terutama yang dilakukan oleh muda-mudi pada saat panen dan menumbuk padi. Semua jenis pantun yang dinyanyikan tidak tertulis dan dinyanykan secara bersahutan antara laki-laki dengan perempuan di sawah, ladang atau di tempat penumbukan padi pada siang hari atau malam hari. Sedangkan tembangtembang atau pantun-pantun yang dibawakan bernama kayaq.

3 Encek adalah panggilan orang Sasak terdahulu sampai sekarang kepada pedagangpedagang, baik etnik Cina maupun pribumi yang datang dari luar Lombok, terutama yang datang dari Banjarmasin-Kalimantan dan Palembang. bicara, tetapi juga untuk seting yang berbeda. Misalnya, pemuda yang akan mengunjungi rumah kekasihnya pada malam hari melantunkan eskpresi ini dalam bentuk lawas (lagunya berbeda) dengan ketika ekspresi tersebut difungsikan sebagai pinjean. Lawas yang dilantunkan oleh pemuda tersebut di samping berfungsi mengungkapkan kata hati, juga membunuh rasa kesepian dan bentuk hiburan diri di waktu malam dalam perjalanan menuju atau pulang dari rumah kekasih/ midang. Pinjean yang digunakan pada siang hari oleh sekelompok gadis yang sedang menanam atau memanen padi beralih fungsi menjadi lakaq/kayaq", (Mahyuni, 2004: 95).

Apabila pandangan di atas dicermati sebagai gejala budaya yang membentuk peradaban masyarakat Sasak, dapat dikatakan bahwa tradisi pinje panje di tengah masyarakat sudah berlangsung lama. Ia tumbuh beriringan dengan terbentuknya masyarakat Sasak awal karena perilaku yang diperlihatkan adalah perilaku yang bersifat alamiah, yang biasa terjadi dalam setiap kelompok masyarakat. Berikutnya, inilah yang mendasari pemikiran bahwa teater Cepung mendapat pengaruh besar oleh tradisi pinje panje yang sudah berkembang di tengah masyarakat.

Pepaosan sendiri pada teater Cepung terdapat pada tuturan yang dibacakan sebagai salah satu unsur penting dari pertunjukan teater Cepung. Pertunjukan teater Cepung 
merupakan pertunjukan yang naskahnya dibacakan langsung dari sumber naskah Tutur Monyeh. Pembacaan naskah yang dilakukan oleh pembaca naskah inilah yang menunjukkan adanya unsur pepaosan di dalam teater Cepung.

Pembacaan dilakukan sambil menyanyikan tembang dalam naskah inilah yang mengindikasikan bahwa teater Cepung dipengaruhi oleh bekayaq. Tembang yang dinyanyikan ini mendorong pemain teater Cepung untuk melahirkan satu irama gerak dan suara dinamis yang kemudian menjadikan pertunjukan teater Cepung memiliki kekayaan bentuk sebagai sebuah seni pertunjukan tradisional.

"Ciri-ciri yang dapat dilihat dalam teater Cepung adalah lontar yang yang dibacanya "hanya" lontar Tutur Monyeh, pembacaan dimulai dengan tetabuhan musik khusus, yakni dengan menggunakan mulut, para pemain duduk membentuk setengah lingkaran, musik dan tari merupakan bagian integral dari pertunjukan, bahasa yang digunakan adalah bahasa Sasak", (Ahmad, 1987: 165166).

Keunikan teater Cepung sebagai seni tradisional adalah terdapatnya tiga unsur seni teater secara bersamaan, yakni musik, tari, dan lakuan. Setiap pemain teater Cepung menggerakkan tubuh mereka sehingga melahirkan gerakan tari sesuai dengan emosi peristiwa di dalam Tutur Monyeh. Tidak hanya itu, tarian tersebut dirangkaikan dengan nyanyian, baik nyanyian yang berupa vokal yang terdiri dari tembang maupun nyanyian yang berupa bunyi, baik bunyi yang dihasilkan oleh gerakan tubuh maupun bunyi dari intsrumen musik pertunjukan teater Cepung. Keunikan tarian dan nyanyian tidak akan terlihat sempurna apabila tidak disertai dengan gerak laku, baik tubuh maupun ekspresi pemain teater Cepung. Meskipun pemain teater Cepung tidak membawakan atau memerankan tokoh sesuai dengan karakter yang ada di dalam naskah pertunjukan teater Cepung, tetapi mereka harus mampu menghadirkan setiap peristiwa dengan gerak laku yang mengindikasikan emosi sedih, marah, bahagia, dan lucu yang sesuai dengan keadaan tokoh dalam cerita. Bahkan, mereka harus mampu memberikan satu penekanan dengan laku tertentu kepada penonton apabila nilai yang hendak disampaikan oleh mereka wajib dipahami oleh penonton.

Sejauh ini, ada tiga periode yang sudah dialami oleh teater Cepung. Pertama, periode di mana teater Cepung masih bersifat pinje panje. Pada periode ini, unsur pertunjukannya masih belum kaya karena Tutur Monyeh belum dituliskan sebagai sebuah naskah utuh. Melainkan hanya berupa cerita lisan yang 
digunakan untuk menyampaikan pesan-pesan agama Islam dan pesan-pesan moral yang berlandaskan nilai-nilai lokal masyarakat Sasak. Pada masa ini, respon masyarakat Sasak terhadap nilai yang terangkum dalam pesan pinje panje sudah mulai terlihat karena penceritaanya dilakukan dari kampung ke kampung. Jero Mihram, sebagai pembawa nilai kepada masyarakat Sasak melalui pinje panje ini sekaligus juga merupakan seorang pemuka agama. Selain itu, Jero Mihram juga berperan sebagai tokoh masyarakat Sasak yang berupaya membangkitkan nasionalisme lokal masyarakat Sasak guna melakukan perlawanan terhadap penindasan penjajah. Melihat respons dan perubahan masyarakat yang cukup signifikan, Jero Mihram mulai menulis beberapa tembang yang sudah dipinje panje-kan.

Periode kedua adalah saat teater Cepung masih sebatas pepaosan. Pada masa ini, naskah teater Cepung sudah ditulis lengkap berupa Tutur Monyeh. Naskah ini tersebar ke seluruh masyarakat Sasak, kemudian masyarakat yang mengenal huruf membacakannya kepada masyarakat lain yang semakin antusias mendengar perkembangan Tutur Monyeh. Dalam periode ini pula bentuk pertunjukan teater Cepung tampak dipengaruhi oleh seni Bejonja'an. ${ }^{4}$ Tradisi Bejonja'an ini dilakukan 4 Bejonja'an merupakan seni tutur masyarakat Sasak yang didominasi oleh hal-hal yang bersifat komedi atau hiburan atau banyolan. Hiburan dalam oleh masyarakat yang sudah mendengar cerita Tutur Monyeh tetapi mereka tidak bisa membaca dan akhirnya mempertunjukkan bagian-bagian tembang yang mereka hapal kemudian dikembangkan menjadi peristiwa komedi atau hiburan.

Perbedaan pepaosan dengan bejonja'an ini terletak pada jumlah pemain. Kalau Pepaosan bisa dilakukan oleh satu orang dan bisa juga lebih serta harus ada naskah yang dibacakan, Bejonja'an mesti dimainkan oleh dua orang atau lebih. Dapat juga dilihat perbedaan bentuk bejonja'an dan pepaosan, yakni bejonja'an sebatas tradisi lisan, sedangkan pepaosan sudah masuk tradisi tulisan. Hal inilah yang menyebabkan bejonja'an banyak dilakukan oleh masyarakat Sasak yang tidak bisa membaca naskah Tutur Monyeh, tetapi memiliki kemampuan menembang dan menghapal beberapa bagian dari Tutur Monyeh yang sudah mereka dengar.

Baik pepaosan maupun bejonja'an masing-masing belum menggunakan alat musik. Semua pemain menirukan alat-alat musik gamelan untuk melahirkan irama musik mulut yang dinamis. Peniruan ini dilakukan

konteks Bejonja'an tidak seutuhnya bermakna hiburan, karena masih terkandung nilai pendidikan nilai di dalamnya. Karena Bejonjaian dalam masyarakat Sasak bukan tanpa batas. Banyolan, hiburan, komedi yang dibawakan masih harus tetap berpegang pada nilai, norma, agama masyarakat Sasak. Itulah sebabnya, meskipun bejonja'an, tetapi tempat yang dipilih adalah tempat yang terbuka. Ini menunjukkan bahwa masing-masing orang yang bejonjaian harus tetap menjaga diri. 
sebagai bentuk perlawanan terhadap penjajah. Mereka ingin menunjukkan bahwa masyarakat Sasak memiliki kemampuan menirukan alat-alat gamelan sebagai bentuk kemampuan yang tidak bisa diremehkan. Selain itu, karena gamelan dalam pandangan Islam pada masa itu dianggap haram, karena identik dengan etnik Bali, maka untuk bisa menembus lapisan masyarakat Sasak, pemain melakukan pencarian-pencarian kreatif. Maka muncul peniruan alat gamelan dengan menggunakan mulut.

Periode berikutnya adalah penggunaan alat musik dalam pertunjukan teater Cepung. Pertama kali dilakukan adalah penggunaan alat musik seruling. Upaya penggunaan alat musik ini dilakukan setelah teater Cepung sampai di Lombok Barat melalui Lombok Tengah bagian selatan. Di Lombok Tengah teater Cepung sempat menyebar di daerah Jelantik dan sekitarnya, kemudian berkembang ke Kuripan, Lombok Barat. Penggerak awal teater Cepung di Kuripan sekitar tahun 1920-an dilakukan oleh Mirasih yang sempat belajar dan menonton pertunjukan teater Cepung di Jelantik, Lombok Tengah. ${ }^{5}$ Perkembangan di Kuripan inilah sebagai muasal terlibatnya etnik Bali dari golongan pedande yang 5 Penelusuran tentang Mirasih tidak membuahkan hasil yang memuaskan karena keturunannya sudah tidak diketahui keberadaannya. Tetapi menurut sejarawan Lombok, Mirasih adalah seorang Muslim taat. Ia berasal dari Kuripan. Mirasih senang belajar ilmu agama sehingga sampai ia pun sempat juga belajar Islam ke Lombok Timur. bekerja sebagai petani, yang memberikan kontribusi memasukkan alat musik seruling ke dalam pertunjukan teater Cepung.

Penelusuran penggunaan istilah "Cepung" dalam teater Cepung sedikit mengalami hambatan karena sedikit sekali naskah tertulis yang menjelaskan asal muasal penggunaan istilah tersebut secara ilmiah. Selain itu, pelaku sepuh yang masih tersisa pun tidak bisa memberikan gambaran menyeluruh tentang penggunaan istilah "Cepung”. Begitu juga dengan budayawan Sasak yang terus memantau perkembangan teater Cepung. Informasi yang mereka dapatkan hanya dari mulut ke mulut selama bertahun-tahun. Inilah kemudian yang dipakai sebagai dasar penelusuran penggunaan istilah "Cepung" dalam teater Cepung.

Bagaimana teater tradisional Cepung ini memperoleh namanya tidak diketahui secara pasti, tetapi dugaan orang ialah dari bunyi iringan yang berbunyi: cek-cek-cek pung. Bunyi ini ibarat gamelan, tetapi dilakukan dengan mulut (Ahmad, 1987: 165). Menurut Mamiq Ambar, istilah Cepung diambil dari nama salah seorang pekerja, buruh kasar waktu pembangunan taman Mayure. ${ }^{6}$

6 Sebagaimana yang dikatakan oleh sejumlah narasumber, tempat ini merupakan salah satu peninggalan kerajaan Hindu Karangasm Bali yang terletak di Cakranegara, Lombok, Nusa Tenggara Barat. Taman ini awalnya bernama taman Kelepung yang pembangunannya sudah dimulai sejak tahun 1800 -an. Penggunaan nama taman Mayure terambil dari nama burung Merak yang dalam bahasa Sanskerta disebut Mayure. Pembangunan ulang taman ini selesai pada tahun 1866 , yang tadinya 
Buruh kasar atau pengayah ${ }^{7}$ itu bernama Cepung. Ia pandai menyanyikan berbagai jenis tembang. Dalam setiap waktu istirahat ia selalu menyanyikan tembang-tembang yang membuat pengayah lain ikut senang mendengarnya. Lama kelamaan, raja pun mendengar kemampuan orang yang bernama Cepung itu sehingga ia diperintah raja untuk terus menyanyi setiap waktu istirahat para pengayah. Setelah teater Cepung berkembang di tengah masyarakat, maka dipakailah nama pengayah bernama Cepung itu sebagai nama teater Cepung. Pendapat lain mengatakan bahwa

"Pada saat raja kerajaan Selaparang yang terkenal sakti dan bijaksana digempur habis-habisan oleh kerajaan Hindu Karngasem Bali, raja memahami keadaan waktu itu bahwa musuh yang dihadapi bukanlah manusia dan tidak mungkin dikalahkan. Oleh karena itu, setelah betempur 117 hari lamanya, raja Selaparang

banyak digunakan untuk memenjarakan para pejuang Sasak yang melakukan perlawanan, selain sebagai tempat penyimpanan harta rampasan, upeti, dan naskah-naskah lontar.

$7 \quad$ Pengayah adalah istilah Sasak yang diperuntukkan bagi buruh dan pekerja kasar. Pada zaman dahulu pengayah ini berasal dari rakyat jelata yang dipandang rendah dan tidak memiliki pekerjaan sehingga penguasa memanggilnya bekerja tanpa upah. Mereka hanya diberikan makan. Tetapi dalam waktu tertentu, dapat juga tanpa upah dan tanpa diberikan makan. Dalam perkembangannya, pekerjaan pengayah ini disebut ngayah yang diadopsi oleh pemerintah dalam menerapkan istilah "Padat Karya” dengan prinsip yang lebih manusiawi, yakni masyarakat diberikan upah, meskipun lebih sedikit dibandingkan dengan upah standar umum. menawarkan persahabatan, lalu mengadakan pesta besar di Dasan Agung. Seusai pesta itu, orang bersenangsenang, menari sambil duduk bersila mengitari sajian tuak, lalu bernyanyi-nyanyi. Pada saat inilah terciptakan yang dikenal sampai sekarang di Karangasem dan Lombok sebagai tari "Cakepung". Laskar Karangasem bersenang-senang menarikan kemenangan. Kata "Cakepung" dikatakan berasal dari "Jag Kepung" yang berarti "kejar terus", (Agung, 1999: 88).

Mengenai penggunaan istilah "Cepung" ada juga pendapat lain yang menyatakan:

"Kata "Cepung" sebenarnya berasal dari peniruan suara atau bunyi alat musik tradisional (gamelan) oleh sekelompok pemain kesenian teater Cepung, seperti "Cekpungcekpung-cekpung-cekpung" dan seterusnya, disuarakan berulang-ulang. Lama kelamaan bunyi ini berubah menjadi "Cepung" sampai sekarang. Pendapat yang berbeda juga menjelaskan bahwa kata "Cepung" sebenarnya suatu istilah dalam bahasa Sasak lama untuk menyatakan "kecuraman" atau "keterjalan" suatu tebing yang sempit dan dalam. Penggunaan kata "Cepung" untuk teater Cepung selaras dengan muatannya yang mengandung nilai-nilai yang bermakna "amat dalam" bagi tata krama kehidupan di masyarakat, terutamaa tentang moral, pendidikan, dan kemanusiaan. 
Nilai-nilai ini dapat dikaji lewat cerita Tutur Monyeh yang merupakan dasar lakon cerita dan keberadaan kesenian ini”, (Suwardie, 1999: 13-14).

Masyarakat Sasak mengenal banyak permainan rakyat. Salah satunya adalah permainan dengan media air. Permainan ini berupa perang air atau memukul-mukul air yang biasanya dilakukan di sungai atau di pinggir laut. Permainan memukul-mukul air ini, apabila dilakukan secara berulang-ulang dan terus menerus maka akan menghasilkan bunyi “cep-ung cep-ung cep-ung”. Bunyi air yang dipukul berulang-ulang dalam permainan air ini merupakan sumber pemberian istilah "Cepung" pada teater Cepung. Kalau pun ini bukan merupakan satu-satunya sumber pemberian istilah pada teater Cepung, pendapat yang menyatakan bahwa pemberian nama dari suara peniruan alat musik oleh pemain teater Cepung waktu masih berbentuk pinje panje, pepaosan, dan bejonja'an dipandang paling mendekarti kebenaran. Misalnya "cep cep-ung cep cep ung cep cep ung", dan seterusnya.

\section{c. Kemampuan Pemain Teater Cepung}

Marinis mengemukakan bahwa "Pertunjukan teater sebagai sebuah peristiwa budaya dipahami sebagai fenomena kesenian yang dihasilkan dari jaringan berbagai elemen eskpresi, yaitu pemeranan (keaktoran), penyutradaraan, ide cerita, naskah (seandainya menggunakan naskah drama), penataan artistik, tempat pertunjukan, dan penonton. Elemen-elemen tersebut diorganisasi untuk menghasilkan sebuah "rekonstruksi" tekstual yang kemudian menghasilkan produksi komunikasi dan penandaan dari penonton (dalam Yudiaryani, 2008: 123124).

Tampak bahwa peran seorang pemain dalam pertunjukan teater Cepung sangat dominan. Produksi komunikasi yang dimaksudkan Marinis merupakan satu peristiwa simultan, baik dalam pengertian bahwa pertunjukan merupakan satu kesatuan elemen artistik maupun kesatuannya dengan penonton yang hendak menginterpretasi pertunjukan. Dalam hal ini, kedudukan seorang pemain menjadi penting.

Pada konteks aktor tradisional, Barba mengistilahkannya dengan "Aktor Timur", aktor mempelajari akting secara mekanik, mengulang secara tepat apa yang diajarkan oleh kebiasaan (Yudiaryani, 2002: 301). Pernyataan ini dapat dibenarkan apabila melihat proses keaktoran yang diperlihatkan oleh pemain teater Cepung.

Kedudukan pemain dalam teater Cepung adalah penting. Setiap jalannya pertunjukan digerakkan sepenuhnya oleh pemain sehingga pemain teater Cepung, menurut Mamiq Ambar, tidak hanya dituntut memiliki "kemauan" untuk mementaskan 
teater Cepung, tetapi juga harus membuang rasa "malu" yang berlebihan serta memiliki "kemampuan" untuk membawakan pementasan teater Cepung. Kemutlakan yang harus dimiliki oleh pemain teater Cepung ada tiga, yang satu sama lain samasama pentingnya. Pertama, pemain teater Cepung harus punya "mau". Kedua, pemain teater Cepung harus sedikit "malu"nya karena teater Cepung berjarak sangat dekat dengan penonton dan hubungannya dengan penonton sangat akrab. Reaksi atas ucapan penonton merupakan juga suatu hal yang tidak terelakkan (Ahmad, t.t.: 166),

Ketiga, pemain teater Cepung diwajibkan "bisa" membawakan atau memainkan pementasan teater Cepung. Sebagaimana yang ditegaskan oleh Mamiq Ambar bahwa boleh saja seseorang memiliki "kemauan" dan sedikit "malu", tetapi ia tidak memiliki "kemampuan" untuk mementaskan teater Cepung, maka pertunjukan teater Cepung tidak dapat dilaksanakan. Pengertian "bisa" pada diri pemain dalam teater Cepung adalah mereka harus benar-benar menguasai bagaimana memainkan teater Cepung, mengerti, dan memahami pesan nilai yang terkandung dalam Tutur Monyeh yang dipertunjukkan ke dalam teater Cepung. Hal yang tidak kalah pentingnya adalah pemain teater Cepung dituntut untuk bisa menjalankan nilai-nilai itu dalam kehidupan mereka sehari-hari. Hal ini karena pertunjukan teater
Cepung menjadi hambar apabila pemainnya sendiri tidak bisa menjalankan nilai yang terkandung di dalamnya sehingga mereka diwajibkan untuk menghindari perilaku buruk seperti perbuatan iri hati dan dengki.

Selain itu, kemampaun mendasar yang harus dikuasai oleh pemain teater Cepung adalah membaca, yakni membaca naskah Tutur Monyeh sehingga setiap pemain teater Cepung mesti memahami jalan cerita serta isi Tutur Monyeh. Meskipun tidak semua pemain teater Cepung berposisi sebagai pemace (pembaca), pemain harus menguasai cerita Tutur Monyeh. Hal ini menjadi penting karena selain demi kelancaran dan kualitas pementasan teater Cepung, juga untuk menjaga diri. Artinya, setiap pemain teater Cepung harus dapat memberikan jawaban apabila ada salah seorang masyarakat yang menonton melontarkan perminataan atau pertanyaan. Mamiq Ambar mengatakan bahwa sejak dahulu semua pemain teater Cepung menguasai betul dan hapal di luar kepala cerita Tutur Monyeh.

Kemampuan berikutnya ialah olah vokal. Pemain teater Cepung dituntut memiliki kemampuan mengolah suara karena salah satu alat utama pemain teater Cepung menyampaikan pesan pertunjukan teater Cepung adalah suara dengan menyanyikan atau menembangakan Tutur Monyeh atau tembang lain yang dinilai memiliki keterikatan nilai dengan Tutur Monyeh. 
Suara tersebut kemudian dieksplorasi untuk membawakan beragam tembang yang menciptakan keunikan tersendiri.

Pemain teater Cepung pada dasarnya tidak memiliki cara khusus untuk melatih vokal mereka. Pengakuan Mamiq Ambar, misalnya. Ia menjelaskan bahwa membawakan tembang dengan berbagai macam teknik vokal tidak didapat melalui proses belajar secara khusus. Dengan demikian, dapat diketahui bahwa kemampuan pemain teater Cepung memanfaatkan suaranya secara maksimal dan dalam tempo pementasan yang panjang disebabkan oleh kebiasaan yang terus dilakukan secara berulang-ulang.

Pemain teater Cepung menggunakan suara yang dilahirkan oleh mulut untuk menirukan bunyi alat musik gamelan. Selain itu, untuk menciptakan berbagai jenis irama yang terkandung dalam tembang pertunjukan teater Cepung. Dapat dikatakan bahwa pada kualitas suara pemain teater Cepunglah letak kehidupan tembang teater Cepung. Pemain teater Cepung menggunakan suara untuk menjadikan bahasa dalam tembang menemukan dan menghadirkan makna yang tersembunyi dalam tembang karena dengan bahasa dalam tembang tersebut pemain teater Cepung berkomunikasi dengan penonton. Makna yang terkandung dalam tembang teater Cepung tersampaikan dengan sempurna oleh karena kemampuan suara pemain teater Cepung menghidupkan bahasa tersebut.

Suara pemain teater Cepung bermakna estetis dan praktis. Artinya, selain pemain teater Cepung dituntut mampu mengolah suara sehingga melahirkan tembang yang menarik, vokal pemain teater Cepung juga dituntut untuk dapat bertahan sepanjang pertunjukan teater Cepung sedang berlangsung. Emosi, pesan, peristiwa, dan segala jenis kejadian yang terkandung dalam Tutur Monyeh ditangkap penonton melalui suara yang diperdengarkan oleh pemain teater Cepung. Keberagaman karakter suara inilah yang menghadirkan satu bentuk komunikasi komunal teater Cepung dengan penonton sehingga menimbulkan rasa sedih, rasa marah, bahkan rasa humor pada diri penonton. Marinis mengatakan bahwa bahasa dan teknik ujaran yang digunakan oleh pemain merupakan bagian penting dalam sebuah teks pertunjukan (Yudiaryani, 2008: 126). Dialog atau interaksi bahasa diucapkan melalui teknik ujaran yang berupa tembang yang dibawakan secara komunikatif, baik antarpemain teater Cepung sendiri maupun ketika tembang tersebut dikomunikasikan dengan penonton.

Selain suara, tubuh pemain teater Cepung tidak kalah pentingnya. Melihat pertunjukan teater Cepung sama halnya dengan memandang pertunjukan teater yang tidak memiliki jeda, terutama pada diri 
pemain. Hal ini disebabkan oleh gerakan tubuh pemain teater Cepung yang tidak pernah berada pada posisi diam yang tidak memberikan makna. Tubuh pemain teater Cepung selalu bergerak karena merespon irama suara yang diciptakan oleh mulut. Gerakan-gerakan yang dihadirkan merupakan satu tanda kekuatan nilai yang terkandung dalam teater Cepung. Hal ini dapat dilihat pada rekasi tubuh pemain teater Cepung setiap menembangkan tembang-tembang yang berbeda. Artinya, masing-masing tembang akan menimbulkan ekspresi tubuh pemain teater Cepung yang berbeda pula. Tampaknya hal semacam ini yang disebut Watson sebagai skor, yakni pertemuan antara tubuh pelaku dengan gerak dan vokal yang ditujukan untuk kepentingan penonton (Yudiaryani, 2002: 303).

Teater Cepung merupakan teater yang mengandalkan kemampuan tubuh pemain karena dengan tubuh seorang pemain melakukan produksi kesenian yang komunikatif. Dalam istilah Marinis, proses kreatif seniman merupakan salah satu pemicu kualitas pertunjukan (Yudiaryani, 2008: 127). Hal ini memberikan pengertian bahwa dengan tubuh, seorang pemain melakukan komunikasi sesama pemain untuk membangun irama pertunjukan sekaligus melakukan pergantian inti cerita dan improvisasi. Hal yang sama juga bermakna bahwa dengan tubuh, pemain teater Cepung menjalin komunikasi dengan penonton. Ketika pesan yang hendak disampaikan memerlukan penekanan, maka seorang pemain teater Cepung akan memberikan penekanan pada tubuhnya dengan membuat gerakan tertentu yang berbeda dengan gerakan sebelumnya dan tidak sama pula dengan gerakan pemain yang lain. Tampak bahwa kemampuan seorang pemain teater Cepung dalam mengolah daya kreatifnya sangat menentukan kualitas pertunjukan teater Cepung.

Tubuh seorang pemain teater Cepung merupakan faktor penting. Melalui tubuh, pemain teater Cepung mengekspresikan tafsir mereka terhadap setiap nilai yang tercantum dalam Tutur Monyeh kemudian ditransformasi dengan daya kreatif berupa tarian unik, yang kadang melahirkan irama tubuh yang lucu, lirih, tegang, penuh emosi, perlahan, dan cepat. Kadang-kadang tubuh juga menjadi sumber bunyi yang menyiratkan tentang emosi tertentu. Misalnya, dengan cara dipukul atau digerakkan dengan teknik yang spesifik sehingga melahirkan efek bunyi yang menambah daya pukau pertunjukan teater Cepung. Pencapaian seorang pemain teater Cepung semacam itu dimungkinkan terjadi karena selain ditentukan oleh tingkat pendalaman mereka terhadap Tutur Monyeh yang sudah matang, juga ditentukan oleh kesadaran mereka terhadap potensi tubuh yang mereka miliki. Tubuh bagi mereka 
adalah alat utama untuk mengekspresikan totalitas pertunjukan teater Cepung. Barba melihat proses pelatihan pemain semacam itu sebagai sebuah gerakan organik sebagaimana yang ia sebutkan dalam dramaturgi teater antropologi

"Aktor yang menggunakan
konsep teater antropologi
untuk mengembangkan
dirinya, sebagai aktor organik.
Aktor organik membutuhkan
waktu bertahun-tahun untuk
mencipta dari suatu ketiadaan
menjadi sesuatu yang lain.
Hal ini membuktikan seberapa
jauh keseiapan seorang
aktor terhadap sesuatu yang
dipercaya dan diucapkannya.
Dalam hal ini tidak bedanya
dengan proses transformasi
individual di antara
transformasi kelompok secara
keseluruhan. Teater mencipta
hubungan antarmanusia",
(Yudiaryani, 2002: 300-301).

Kemampuan pemain teater Cepung mengeksplorasi tubuh sebagai bahasa ungkap pemahaman mereka terhadap Tutur Monyeh menunjukkan suatu proses yang tidak mudah dan bukan dalam waktu yang singkat, melainkan ketekunan mengolah daya tubuh hingga benar-benar menjadi satu kesatuan yang mencipta kualitas pertunjukan teater Cepung yang memadai. Maka, melihat proses pengolahan tubuh pemain teater Cepung tidak berlebihan jika dinilai sebagai sebuah proses keaktoran teater antropologi.

Tidak jarang, salah seorang pemain teater Cepung memukul-mukul badannya yang disangkakan sakit oleh penonton, tetapi sebenarnya tidak karena mereka menggunakan cara tersendiri. Karena teater Cepung merupakan satu gerakan perlawanan melalui kesenian terhadap penjajah yang juga identik dengan alat musik gamelan, maka pemain teater Cepung dituntut dapat menirukan semua jenis alat musik gamelan dengan tubuh mereka. Faktor ini yang dipandang sebagai salah satu penyebab munculnya kesadaran pengolahan tubuh pemain teater Cepung hingga sampai pada puncak daya kreatif seorang pemain. Perlawanan melalui tubuh ini memberikan makna tinggi pada teater Cepung sebagai sebuah kesenian yang memiliki hubungan erat dengan manusia sebagaimana yang dikemukakan oleh Barba di atas. Peniruan suara seruling dan gong, pemain teater Cepung menggunakan mulutnya sehingga menghasilkan bunyi yang sama. Untuk memberikan kesan bahwa alat musik yang sedang ditirukan adalah seruling dan gong, pemain teater Cepung menggunakan tubuh agar penonton mengetahui dengan jelas.

Tubuh merupakan wadah aktor mengekspresikan pemahaman dirinya terhadap Tutur Monyeh, yang kemudian ditransfer kepada penonton guna berbagi pengetahuan. Kejadian ini menimbulkan keterpukauan pada diri penonton sekaligus pelibatan intelektual penonton secara langsung dengan pertunjukan teater Cerpung 
yang sedang berlangsung. Sebagaimana yang dikatakan oleh Barba bahwa keseimbangan tubuh seperti yang diperlihatkan oleh pemain teater Cepung menunjukkan kekuatan energi sebuah bentuk. Bentuk yang terdiri dari rangkaian potensi yang berbeda-beda dari organ tubuh pemain. Bentuk tersebut mampu memperkuat dan menghidupkan tubuh itu sendiri (dalam Yudirayani, 2002: 302). Namun demikian, tidak berarti bahwa meskipun sumber penciptaan teater Cepung adalah Tutur Monyeh, pemain teater Cepung menirukan gerakan-gerakan kera karena gerakan tarian atau gerakan tubuh pemain secara keseluruhan merupakan akibat dari irama tembang yang dibawakan. Bukan peniruan gerakan tokoh yang ada dalam Tutur Monyeh.

Konsep dasar yang dipegang oleh pemain teater Cepung dalam mengolah tubuh mereka adalah pengolahan melalui "kebiasaan". Apabila dilakukan secara terusmenerus, maka tubuh akan terbiasa untuk menerima atau merespons apa yang mereka pikirkan dalam sebuah pertunjukan. Tidak ada latihan khusus. Hal ini memiliki relevansi dengan teori Barba terkait proses keaktoran teater antropologi yang membutuhkan waktu lama untuk sampai pada taraf menghidupkan tubuh sendiri. Pemain teater Cepung tidak mewarisi pola-pola latihan yang khusus yang oleh Barba disebut sebagai sats "Yaitu energi yang diam tetapi telah disiapkan sebelum pemain bergerak. Sesaat sebelum gerak terjadi ketika seluruh tenaga siap dilepaskan tetapi tertahan dan tetap terkontrol. Pada saat pemain berpikir tentang gerak, maka gerak akan terjadi melalui peregangan. Bahkan dalam posisi pemain diam, gerak pun terjadi (Yudiaryani, 2002: 303).

Latihan pemain dalam konteks teater Cepung adalah bagaimana mereka menyelaraskan diri, baik pemahaman dan maupun bentuk-bentuk lakuan mereka di atas pentas. Meskipun tidak jarang terjadi pengembangan melampaui apa yang sudah mereka selaraskan sebelumnya. Hal ini biasanya disebabkan oleh kemampuan masing-masing pemain dalam merespons kontekstualitas masyarakat yang sedang menonton, sebagaimana yang ditekankan oleh Barba bahwa teater antropologi adalah metode atau cara seniman untuk mengolah dan memanfaatkan energi tubuh manusia untuk kepentingan pementasan (Yudiaryani, 2005: 90).

Dalam konteks ini, pemain teater Cepung memanfaatkan metode yang mereka temukan sendiri melalui pementasan bertahun-tahun sehingga menemukan energi diri mereka sendiri. Artinya, energi tersebut tidak dapat dikembangkan menjadi milik atau energi orang lain. Dengan kata lain, setiap energi yang terdapat pada masing-masing pemain teater Cepung hanya dapat disatukan 
ketika pementasan sedang berlangsung untuk menciptakan komunikasi energi dengan penonton melalui gerakan yang mereka hasilkan. Barba mengatakan bahwa energi bersifat abstrak, sedangkan gerak berbentuk konkret. Melalui gerak, penonton akan dapat merasakan energi yang disalurkannya (Yudiaryani, 2005: 90).

Ada tiga bagian utama pada tubuh seorang pemain teater Cepung. Pertama, bagian atas yang terdiri dari ekspresi wajah. Kedua, bagian tengah, yang terdiri dari anggota badan yang tengah seperti tangan, dada, pundak, bahkan perut. Ketiga, bagian bawah yang terdiri dari kaki. Ekspresi wajah pemain teater Cepung tampak dilebihkanlebihkan, namun tidak berarti demikian karena ekspresi tersebut merupakan kemurnian yang timbul dari penjiwaan pemain terhadap lakuan yang sedang dibawakannya. Hal yang menarik lainnya, meskipun teater Cepung menggambarkan tentang perjalanan Monyeh, tidak satu kali pun pemain teater Cepung memperlihatkan ekspresi yang menyerupai kera bagi mereka, bukan pada kera yang diverbalkan makna teater Cepung ingin disampikan melainkan pada ekspresi yang diperlihatkan pemain teater Cepung dalam setiap jalinan peristiwa yang dialami oleh tokoh Monyeh. Pada bagian ekspresi tubuh yang lain, pemain teater Cepung pun tidak menghadirkan peristiwa dalam Tutur Monyeh secara verbal atau tidak menirukan gerakan- gerakan yang menyerupai kera. Melalui eskpresi wajah, pemain teater Cepung menghadirkan kandungan makna yang terdapat di dalam teater Cepung. Misalnya, bagaimana cara menyikapi keadaan sedih atau penderitaan yang dialami oleh manusia yang diperlihatkan pada tokoh-tokoh yang ada di dalam Tutur Monyeh. Melalui wajah pula pemain teater Cepung menghadirkan seluruh peristiwa yang terjadi pada masingmasing tokoh. Barba dalam (Yudiaryani, 2005:81) mengatakan bahwa;

"Keseimbangan tubuh dan konsentrasi penuh mampu mendukung pelaku mencipta gerak-gerak yang dinamis. Gerak yang "meruang" hasilnya adalah banyaknya bentuk-bentuk gerak yang tercipta dengan memiliki banyak makna. Inilah "tari keseimbangan" yang menjadi prinsip mendasar bagi seorang pelaku di atas panggung teater".

Bagian tengah tubuh pemain teater Cepung memberikan keseimbangan antara ekspresi yang dihadirkan oleh bagian tubuh atas dan gerakan yang diciptakan oleh bagian tubuh bawah. Tangan pemain teater Cepung, misalnya, lebih banyak memperlihatkan gerakan tangan yang terbuka. Ini menandakan bahwa karakter masyarakat Sasak terbuka kepada setiap orang. Tangan pemain teater Cepung diletakkan dengan posisi kedua telapak tangan saling menggenggam di atas lutut. Sikap ini menandakan kepandaian masyarakat Sasak menghormati orang lain 
dan menempatkan diri sejajar dengan cara memberikan penghormatan kepada orang lain.

Sekali waktu, tangan pemain teater Cepung diangkat ke atas. Hal ini biasanya dilakukan untuk menunjukkan kekuasaan Tuhan Yang Maha Esa. Begitu juga ketika kedua tangan diletakkan di atas lantai tempat pertunjukan teater Cepung sedang berlangsung, sikap ini menunjukkan satu kecendrungan karakter masyarakat Sasak yang menyukai perdamian. Hal yang paling menonjol pada bagian tubuh paling bawah pemain teater Cepung adalah telapak kaki yang diletakkan di atas paha. Apabila tidak untuk sesuatu yang sangat penting, seperti menjaga keseimbangan tubuh atau mengubah posisi tubuh, telapak kaki ini tidak akan pernah dilepaskan dari atas paha. Sepanjang pertunjukan teater Cepung, telapak kaki ini terus bergerak sesuai dengan irama dan emosi yang sedang berlangsung dalam pertunjukan teater Cepung. Tampaknya, ini merupakan satu bentuk zikir yang mengingatkan manusia untuk selalu ingat kepada Yang Maha Berkuasa.

Dalam hal ini Aswandikari menilai bahwa melalui pendekatan tasawuf Sasak yang memuat bunyi kata seperti toyyibah, yakni Subhanallah, Astaghfirullah, Lalilaha illallah, Alhamdulillah, Allahuakbaryangjika diucapkan secara terus menerus seperti dalam zikir pasti menimbulkan gerakan tubuh yang di luar kesadaran penzikir tersebut. Dalam tasawuf banyak dijumpai hal demikian, termasuk juga di kalangan masyarakat Sasak yang bertarekat Naqsabandiyah. Ini memiliki hubungan dengan teater Cepung yang memang sejak awal sudah digunakan untuk menyebarkan ajaran Islam. Untuk itu, apa yang diperlihatkan oleh pemain teater Cepung dapat dinilai sebagai sebuah zikir kepada Allah SWT. Kemampuan selanjutnya ialah pengolahan rasa. Barba dalam (Yudiaryani, 2002: 300) mengatakan;

"Dalam teater antropologi, pelaku didorong memasuki proses kreatif dan sepanjang kreativiats berlangsung. Artinya, kreativitas dan usaha dekonstruksi yang mencerminkan kegiatan kreatif akan menyebabkan setiap babakan kreasi melahirkan pergeseran dan pencabangan makna baik dari sudut komunikasi maupun resepsi. Segala sesuatu terkait dari "pra-gerak" hingga "gerak yang tercipta" dan berakhir hingga "pemaknaan" yang diutarakan oleh gerak, yakni bukan semata gerak fisik tetapi gerak batin pelaku. Kreativitas pelaku memerlukan kode serta ikon yang mampu mewujudkan reaksi-reaksi tubuh, pikiran, dan batin pelaku".

Penjelasan Barba di atas memberikan pengertian bahwa sebelum pemain teater mempertunjukkan kemampaun di atas 
pentas, pemain tersebut harus melakukan pengolahan tubuh, batin, dan vokal secara mendalam guna melahirkan kualitas lakuan. Jelas bahwa ketiga alat pemain, yakni tubuh, vokal, dan batin menjadi sangat penting dan berada dalam kesatuan yang selanjutnya diimbangi oleh kemampuan pemain mengolah daya pikir.

Batin seorang pemain berperan penting dalam meningkatkan kualitas komunikasi dengan penonton karena dengan batin seorang pemain memberikan makna untuk diresepsi oleh penonton berdasarkan kemampuan dan pengalaman batin masingmasing penonton. Dalam konteks teater Cepung, batin merupakan ketajaman rasa yang dimiliki oleh pemain teater Cepung. Dengan kedalaman batin, pemain teater Cepung memasuki setiap makna yang terkandung di dalam lontar Tutur Monyeh. Makna lainnya ialah tidak hanya penalaran logika yang dapat memberikan seseorang, termasuk pemain teater Cepung menangkap nilai-nilai yang terkandung dalam teater Cepung, melainkan harus pula memahami tasawuf dalam hal ini batin masyarakat Sasak. Memahami proses perjalanan penempaan batin masyarakat Sasak yang dimaksudkan oleh pernyataan di atas adalah perjalanan kesejarahan masyarakat Sasak. Dengan kata lain, apa yang terkandung di dalam Tutur Monyeh dan semua yang ditampilkan dalam pertunjukan teater Cepung merupakan representasi dari perjalanan batin masyarakat Sasak. Dengan demikian, memahami perjalanan kesejarahan masyarakat Sasak merupakan satu sarat untuk dapat mengerti setiap nilai yang terkandung di dalam teater Cepung.

Kerja pertama seorang pemain teater Cepung adalah mengolah pikiran karena dengan pengolahan pikiran ini kedalaman batin akan ditemukan. Artinya, pemain yang benar-benar memainkan pertunjukan teater Cepung dengan kedalaman rasa juga akan memperlihatkan penguasaan dan pemahaman terhadap kandungan nilai yang ada dalam teater Cepung. Dengan kedalaman pemahaman dan kematangan rasa semacam ini, pemain teater Cepung telah berada pada posisi yang siap dalam kondisi apa pun ketika pertunjukan sedang berlangsung. Sebagaimana yang dikatakan oleh Barba bahwa pengasahan fisik, vokal, dan batin diperlukan untuk mempersiapkan diri pemain guna mengarahkan dinamika gerak fisik, vokal, dan batin pemain kepada penonton (Yudiaryani, 2002: 303).

Kemampuan berikutnya ialah cara pemain mengorganisasi diri. Pengorganisasian diri pada internal pemain teater Cepung dimaksudkan pada dua hal. Pertama, pada bagaimana pemain teater Cepung mematangkan kualitas pertunjukan. Kedua, pada bagaimana pemain teater Cepung meregenerasi diri. Pemain teater 
Cepung tidak mengenal latihan rutin yang diatur secara sistematis atau terjadwal, melainkan tiap-tiap pemain sama-sama saling percaya kualitas masing-masing. Hal ini dapat diartikan bahwa pertunjukan teater Cepung saat diundang pentas, hal tersebut merupakan latihan sekaligus. Artinya semakin sering pemain diundang, maka semakin matang dalam mementaskan teater Cepung, baik fisik, vokal, rasa, maupun pemahaman terhadap nilai yang terkandung dalam pementasan yang dibawakan.

Berpijak pada pola di atas, maka tidak dapat ditemukan sistem pelatihan baku pada diri pemain teater Cepung. Hal ini semakin mempertegas bahwa talenta alamiahlah sebagai pendorong pertama pemain teater Cepung, baru kemudian dimatangkan oleh pengalaman. Dengan kata lain, pengalaman sangat berperan dalam baik buruknya penampilan pemain teater Cepung. Namun demikian, biasanya pemain teater Cepung memiliki pengalaman pentas yang banyak dan berlangsung dalam kurun waktu bertahun-tahun. Hal inilah tampaknya yang dinilai oleh Barba sebagai sebuah pola pelatihan yang tanpa kenal lelah baik fisik maupun vokal, seperti juga pengungkapan emosi dan psikis pemain yang berlangsung secara terus-menerus (Yudiaryani, 2002: 300). Namun demikian, yang dimaksudkan dengan terus-menerus dalam pemain teater Cepung bukan pada kontinuitas latihan yang sistematis melainkan padajumlah penampilan yang berlangsung selama berpuluh-puluh tahun. Pengalaman pentas yang berlangsung selama bertahun-tahun ini, pada satu sisi melahirkan kematangan pemain teater Cepung, baik fisik, vokal, maupun rasa atau batin, dan kedalaman pemahaman mereka terhadap kandungan nilai teater Cepung. Akan tetapi, pada sisi yang berbeda pola semacam ini pula yang ternyata menghambat terjadinya regenerasi secara teratur. Sebagai sebuah kesenian tradisional, teater Cepung memiliki sistem pelatihan pemain yang dikelola dan digerakkan secara tradisional pula. Untuk melakukan penelaahan secara lebih mendalam tentang sistem pelatihan pemain ditemukan kesulitan-kesulitan, baik yang bersifat teknis maupun kepustakaan. Misalnya, pemain teater Cepung tidak dapat menjelaskan bagaimana sistematika pelatihan mereka secara terstuktur, melainkan hanya berdasarkan transformasi pengalaman yang mereka rasakan. Di samping itu, tingkat pendidikan mereka tidak mampu merekam jejak latihan yang sudah terlampaui.

Sistem perekaman jejak yang hanya bersifat empirik ini pula yang menjadikan faktor penyebab tersumbatnya regenerasi yang dilakukan secara sistematis. Hampir semua pendahulu teater Cepung yang sudah meninggal tidak memiliki generasi penerus. Bahkan Mamiq Ambar sendiri bukan berasal dari keluarga yang sejak awal menekuni teater 
Cepung. Ia menjadi pemain teater Cepung karena secara kebetulan tinggal di lingkungan yang dinamika keseniannya terjaga, yakni di perkampungan Selimur, Dayen Mayure (utara Taman Mayure) sehingga begitu ada kesempatan untuk mengambil peran sebagai pemain teater Cepung, ia pun memulai kesempatan itu sebagai permulaan tersebut. Ironisnya, Mamiq Ambar juga tidak memiliki generasi penerus yang lahir dari darah dagingnya. Dengan demikian, sistem regenerasi dalam teater Cepung digerakkan oleh faktor lingkungan dan faktor keinginan, ketertarikan, dan kemauan calon pemain tersebut untuk mempelajari teater Cepung.

\section{Simpulan}

Mengacu kepada diskusi di atas, maka dapat disimpulkan beberapa hal sebagai berikut:

Pertama, awal mula munculnya teater Cepung menunjukkan bahwa tradisi lisan masyarakat Sasak secara tegas memengaruhinya. Meskipun sumber teks penciptaanya ialah lontar Tutur Monyeh, namun kelisanan yang sudah melekat dalam teater Cepung tidak serta merta terkaburkan. Hal ini disebabkan oleh dasar kemunculannya tidak dapat dilepaskan dari sejarah dan pandangan hidup masyarakat Sasak terutama aspek yang berkaitan dengan agama Islam.

Kedua, Kemampuan dasar pemain tetaer Cepung selalu bermula dari ketajaman mereka memahami teks Tutur Monyeh dan konteks masyarakat Sasak. Ini memaknakan bahwa lisan dan tulisan ialah rangkaian paradigma kebudayaan masyarakat Sasak dalam menyusun corak kesenian mereka. Tidak dapat dielakkan bahwa pemain teater Cepung memiliki pendidikan yang rendah, namun sistem pemaknaan terhadap konteks teks Tutur Monyeh yang terwarisi secara mendalam membuat mereka secara jernih melihat persoalan dalam teks dan konteks.

Ketiga,darisudutpandang pertunjukan pemain, dapat dilihat bahwa tubuh, suara, rasa, dan sistem pengorganisasian diri mereka memang belum terbakukan secara modern, namun sikap kesenian dan keyakinan hidup telah melatih kematangan mereka untuk memahami kaidah keaktoran modern. Atas dasar ini, dapat ditegaskan bahwa baik kemampuan keaktoran mupun sistem pemaknaan mereka sesungguhnya memberikan corak dramaturgi keindonesaan yang berfungsi juga sebagai antitesis sistem lakon modern yang mendunia. 


\section{Daftar Pustaka}

Ahimsa-Putra, Heddy Shri. (Mei 1998), "Sebagai Teks dan Konteks Seni dalam Kajian Antropologi Budaya" dalam SENI, Jurnal Pengetahuan dan Penciptaan Seni, VI/01, BP ISI Yogyakarta: Yogyakarta.

Ahmad Muhidin, Lalu. (1976), Monyeh Transkripsi Lontar, Sub Proyek Pengembangan Media Kebudayaan Nusa Tenggara Barat: Mataram

Ahmad, Kasim. (tt), Ungkapan Beberapa Bentuk Kesenian, Teater, Wayang dan Tari, Direktorat Kesenian Proyek Pengembangan Kesenian, Departemen Pendidikan dan Kebudayaan: Jakarta.

Asy' ari, Musa. (Januari 2001), "Spiritualitas Seni dan Agama dalam Islam” dalam SENI, Jurnal Pengetahuan dan Penciptaan Seni, VIII/03, BP ISI Yogyakarta: Yogyakarta.

Ketut Agung, Anak Agung. (1991) Kupu-kupu Kuning yang Terbang di Selat Lombok, Lintasan Sejarah Kerajaan Karangasem (1661-1950) Upada Sastra: Denpasar.

Koentjaraningrat. (1989), Metode-metode Penelitian Masyarakat, Gramedia: Jakarta.

Mahyuni. (Februari 2004), "Indirectenss Pada Masyarakat Sasak: Fenomena Metafor", dalam Linguistik Indonesia, Jurnal Ilmiah Masyarakat Linguistik Indonesia: Jakarta.

Nazir, Moh. (2005), Metode Penelitian, Ghalia Indonesia: Bogor.

Soedarsono, R.M.(2001) Metodologi Penelitian Seni Pertunjukan dan Seni Rupa, Masyarakat Seni Pertunjukan Indonesia: Bandung.

Strauss, Anselm \& Corbin, Juliet. (2003), Basic Of Qualitative Research: Grounded Theory Procedures and Techniques atau Dasar-dasar Penelitian kualitatif: Tatalangkah dan Teknik-teknik Teoritisasi Data, terjemahan Muhammad Shodiq \& Imam Muttaqien. (2007), Pustaka Pelajar: Yogyakarta.

Subiyantoro, Selamet. (Mei 1999), "Perubahan Fungsi Seni Tradisi: Upaya Rasionalisasi Terhadap Pengembangan dan Pelestarian Kebudayaan", dalam SENI, Jurnal Pengetahuan dan Penciptaan Seni, VI/04, BP ISI Yogyakarta: Yogyakarta.

Sudirga, I Komang. (2005), Cakepung, Ansambel Vokal Bali, Kalika Press: Yogyakarta.

Suwadi, Lalu. (1991), Deskripsi Tari Gendang Beleq Daerah Nusa Tenggara Barat, Departemen Pendidikan dan Kebudayaan Kanwil Propinsi NTB: Mataram.

Suwardie, H. AH. (1999), Deskripsi Cepung Kesenian Tradisional dari Lombok Nusa Tenggara Barat, Departemen Pendidikan dan Kebudayaan Kanwil Propinsi NTB Proyek Pembinaan Kesenian NTB: Mataram.

W. Bactiar, Harsja. (1977), "Pengamatan Sebagai Suatu Metode Penelitian", dalam Koentjaraningrat, Metode-metode Penelitian Masyarakat, Gramedia: Jakarta.

Wignjosoebroto, Soetandyo. (1989), "Pengolahan dan Analisa Data", dalam Koentjaraningrat, Metode-metode Penelitian Masyarakat, Gramedia: Jakarta.

Yudiaryani. (2002), "Panggung Teater Dunia: Perkembangan dan Perubahan Konvensi", Pustaka Gondosuli: Yogyakarta.

Yudiaryani. (2005), “Teater Antropologi: Teknik Gerak Tubuh bagi Teater Panggung, dalam SELARONG, Volume 04, Dewan Kesenian Bantul: Yogyakarta.

Yudiaryani. (April 2008), “Analisis Tekstual Pertunjukan Marco de Marinis (Teks-KonteksInterteks)" dalam EKSPRESI, Jurnal Penelitian dan Penciptaan Seni, VIII/01, BP ISI Yogyakarta: Yogyakarta.

Zakaria, Fath. (1998) Mozaik Budaya Orang Mataram, Yayasan Sumur Emas: Mataram 